\title{
Integration of a Constructivism Approach in E-learning Photography Subjects: Feasibility and Effectiveness in Learning
}

\author{
Andi Kristanto ${ }^{1 *}(\mathrm{D})$ \\ ${ }_{1}$ Prodi Teknologi Pendidikan, Universitas Negeri Surabaya, Surabaya, Indonesia \\ e-mail: andikristanto@unesa.ac.id
}

\section{A R T I C L E I N F O}

Article history:

Received March 29, 202

Revised April 01, 2021

Accepted May 01, 202

Available online May 25, 2021

Kata Kunci:

E-Learning, Konstruktivistik,

Kelayakan, Keefektifan

Keywords:

E-Learning, Constructivist,

Feasibility, Effectiveness

\begin{abstract}
A B S T R A K
Permasalahan serius dan harus segera diatasi pada pembelajaran matakuliah fotografi adalah kurangnya waktu perkuliahan karena banyaknya materi, minimnya jumlah kamera foto tidak sebanding dengan jumlah mahasiswa, pembelajaran konvensional melalui tatap muka dengan menggunakan powerpoint, sehingga mahasiswa bosan dan kurang tertarik dalam pembelajaran. Tujuan dari penelitian ini adalah untuk mengembangkan e-learning dengan pendekatan konstruktivistik pada matakuliah fotografi materi triangle exposure, serta untuk mengetahui kelayakan dan keefektifan produk. Penelitian ini merupakan jenis penelitian $R \& D$ (Reseacrh and Development) menggunakan model ADDIE, yaitu Analize, Design, Development, Implementation, and Evaluation. Penelitian ini melibatkan 3 validator yakni ahli desain pembelajaran, ahli materi, ahli media dan subjek mahasiswa terdapat kelas kontrol dan eksperimen dengan jumlah sampel sebanyak 80 mahasiswa per kelas. Metode pengumpulan data menggunakan instrumen angket dan tes. Metode analisis datanya menggunakan deskriptif persentase dan uji independent sampel t-test. Hasil penilaian rata-rata persentase masing masing ahli adalah: (a) penilaian ahli desain pembelajaran 96,66\% kategori sangat baik; (b) ahli materi 95\% kategori sangat baik; (c) ahli media 95,58\% kategori sangat baik, uji coba perorangan $84,05 \%$ kategori sangat baik, uji coba perorangan 88,37\% kategori sangat baik. Efektifitas e-learning konstruktivistik dengan hasil signifikansi pada kolom Sig (2-tailed) sebesar 0,00 atau signifikansi < 0,05. Berdasarkan hasil penelitian yang diperoleh dapat disimpulkan bahwa e-learning dengan pendekatan konstruktivistik layak dan berimplikasi efektif digunakan dalam perkuliahan pada matakuliah fotografi.
\end{abstract}

\section{A B S T RA C T}

Lack of lecture time was a serious problem and must be addressed immediately in the study of photography courses because of the large amount of material; the number of cameras is not comparable to that of students. Moreover, conventional learning through the face of the muka by using PowerPoint makes students bored and less interested in learning. This research aimed to develop e-learning with a constructive approach to photography subjects triangle exposure material and know the feasibility and effectiveness. This research was a type of research $\mathrm{R} \& \mathrm{D}$ (Research and Development) using the Addie model, Analyze, Design, Development, Implementation, and Evaluation. This study involved three validators, namely learning design experts, material experts, media experts and student motorcycle taxis, and there were control classes and experiments with a sample count of 80 students per class. The method of collecting data using questionnaire instruments and tests. Method analysis data using descriptive percentage and independent test $t$-test samples. The average assessment results of each expert's percentage were: (a) the assessment of learning design experts $96.66 \%$ of the excellent category; (b) material experts $95 \%$ excellent category; (c) media experts $95.58 \%$ excellent category, individual trials $84.05 \%$ excellent category, individual trials $88.37 \%$ excellent category. The effectiveness of constructivist $e$-learning with significant results in sig (2-tailed) column of 0.00 or significance of $<0.05$. Based on the research results obtained, e-learning with a viable constructivist approach and effective implications used in lectures on photography courses.

This is an open access article under the CC BY-SA license.

Copyright (C) 2021 by Author. Published by Universitas Pendidikan Ganesha.

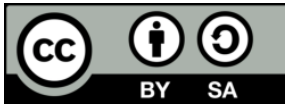

\section{INTRODUCTION}

21 st-century education is marked by the era of industrial revolution 4.0 known as the century of openness and globalization. The utilization of technology and its development in the world of education is increasingly advanced and developing, so it requires many updates to keep pace with these developments (Amalia \& Brata, 2018; Husaini, 2014). The Covid-19 virus pandemic is currently hitting Indonesia. Virus is very high spread (Fitriyani et al., 2020; Pratama et al., 2020). Various policies have been implemented. These 
policies have led to the implementation of learning conducted online. By looking at the current conditions, the world is required to adjust the development of technology to continuously improve the quality of education, especially in the learning process. Learning by using technology information can provide convenience for students to obtain information and learning resources anywhere and anytime (Amalia \& Brata, 2018). The rapid development of technology can be used well in the world of education certainly has a positive effect on learning. Implementing learning using technology can be done anywhere without having to be in a classroom or be done without face-to-face (Baragash \& Al-Samarraie, 2018; Tantu \& Christi, 2020).

Learning media is very important as a tool to channel the message in a planned manner that can represent lecturers in delivering a material more clearly, thoroughly, interestingly, and facilitate students in understanding a learning material delivered to be more efficient and effective (Bahtiar, 2019; Nurrohmah et al., 2018). Using learning media to facilitate interaction between lecturers and students so that learning activities are more effective and efficient (Herliana \& Anugraheni, 2020). Learning activities in universities are currently considered still not implemented to the maximum, sothe results are not optimal. The main cause of not optimal learning activities can be seen from the side of learners and learners. From the perspective of the learner, the reason is not yet the maximum of a learning activity because 3 (three) things, namely the learner has not been able to organize learning activities following the demands of the development of the times that are certainly in the field of educational technology, learners are still mistaken in interpreting the learning process, learners still use learning concepts that are not relevant to the development of educational technology. From a student's perspective, the cause is not yet maximal learning activities because students still lack in thinking. Students can be said to lack in thinking because students undergo activities on campus only listen to the explanation of learners, and students do not try to understand the content/material of the course seriously (Mustaji, 2017; Nurhusain, 2017).

Aside from students and lecturers' perspective, not yet the maximum of learning activity can be caused by a learning process itself. The learning process is less than the maximum due to 2 (two) things; namely, the learning process contains only information, has not led to an active student process to build their knowledge independently, the learning process is still centred on learners, has not been directed at student-centred learning. The atmosphere in learning is boring, not yet directed to an interesting and fun learning atmosphere. The learning process is still mostly informative only (Kristanto et al., 2017). The results of interviews with learners found problems in learning in the course of photography, namely first, the lack of lecture time by looking at the amount of material that must be delivered. Second, the lack of the number of photo cameras for students to use for practice. Third, Learners in classroom learning only use conventional learning/lectures through face-to-face using PowerPoint, so that students are bored and less interested in learning. This kind of learning situation describes an active learning activity in providing information so that students are passive because the student activities only listen to, record and do the task given. Learners are more inclined to use behavioristic approaches. The method used in lectures is considered less interesting to students, because learning is only centred on learners only and learners are only passive listeners (Sundari, 2019).

Learning in the 21 st century has several principles (Nichols, 2013). One of the main principles is that learning should be student-centred. Students are placed as active learning subjects in their studies. Students are no longer required to memorize lecture materials but build their knowledge following the level and capacity of the development of thinking. In this era students should be able to access and analyze existing information (Barry, 2012). To be able to accommodate the importance of using ICT, the solution is to apply e-learning. Worldwide, online learning usage has increased in recent years, that more than $80 \%$ of all students in higher education take at least one online course (Berga et al., 2021; Maarop \& Embi, 2016). Based on a survey, online learning has achieved a growth of $46 \%$ per year worldwide (Hilliard, 2015). E-learning is an innovation in the world of education, where this learning provides many roles and functions that are very large for the world of education. E-learning as a form of learning model facilitated and supported by the use of information and communication technology (Hanum, 2013). In addition, materials can be enriched through various learning resources and can be updated by lecturers. Online learning can involve students in thinking and learning more effectively, faster, and more in-depth than in the traditional way by reading a book or through regular face-toface learning in the classroom (Sudiarta \& Suweken, 2014).

E-learning can bring a new atmosphere in various learning developments. Good use of e-learning can improve learning outcomes to the maximum. Some of the benefits of e-learning, include (1) with $e$-learning can shorten learning time and make learning costs more efficient; (2) e-learning facilitates interaction between students and materials; (3) students can exchange information and be able to access learning materials at any time and repeatedly. Thus the student can further strengthen the mastery of the learning material; (4) With $e$ learning, the process of knowledge development occurs in the classroom, but with the help of computer devices and networks, students can be actively involved in the teaching and learning process (Müller et al., 2021; Rohmah, 2016). E-learning in universities is expected to provide other benefits, among others: (1) there is an increase in student interaction with each other and with lecturers; (2) the availability of unlimited learning 
resources; (3) well-developed e-learning will be effective in improving the quality of graduates and the quality of universities; (4) the establishment of a learning community that interacts with each other, gives and receives and is not limited to one location; (5) improving the quality of lecturers because it is possible to dig more information even indefinitely (Hartanto, 2016). Thus, the novelty of this study is e-learning using a constructive approach. This research aims to develop e-learning with a constructive approach to photography courses and know the feasibility and effectiveness of the product.

\section{METHOD}

This type of research was development research that aims to produce a product. This development research in the FIP Unisa Education Technology Study Program with respondents amounted to 80 experimental class students and 80 control class students. Data collection methods were questionnaires and tests-furthermore, data analysis techniques using analysis Likert scale assessment and independent t-test analysis. Prosedur development research using the ADDIE model consists of five stages: Analize, Design, Development, Implementation, and Evaluation (Mabruri et al., 2019; Smaldino et al., 2012). The initial process of this research began by analyzing the needs through observation and interview to photograph the ideal conditions with actual conditions to find the gap between the two, analyze the material taught, analyze the characteristics of students, and formulate learning objectives. Next, design an e-learning flow chart design and design a learning tool to make it more structured. The third step was developing e-learning and RPS; all pre-prepared plans were executed to become ready-to-use products and tested on the subject and validator at this stage. The validators in this study were the master validators of learning design, the material expert validators and the expert validators of learning media.

Table 1. Likert Scale Assessment Analysis

\begin{tabular}{cc}
\hline Score & Criteria \\
\hline 5 & Strongly agree \\
4 & Agree \\
3 & Neither Agree nor Disagree \\
2 & Disagree \\
1 & Strongly Disagree \\
\hline
\end{tabular}

(Arikunto \& Cepi, 2010)

In giving meaning to percentage numbers, as a result of the calculation by using the above formula that was associated with determining whether e-learning media with this constructivist should be revised or not, the following criteria were used.

Table 2. Development Product Feasibility Assessment Criteria.

\begin{tabular}{cc}
\hline Persentase & Criteria \\
\hline $81 \%-100 \%$ & Excellent / Very Decent \\
$61 \%-80 \%$ & Good / Decent \\
$41 \%-60 \%$ & Less / Less Worthy \\
$21 \%-40 \%$ & Not good / Not Worth it \\
$0 \%-20 \%$ & Very / Unworthy \\
\hline
\end{tabular}

Based on table 2, the calculation shows the percentage of each aspect in the range: $81 \%-100 \%$ or 61 $\%-80 \%$, then the aspect is declared very well or good and does not need to be revised. However, if thepercentage value indicates that each aspect is in the range of $41 \%-60 \%, 21 \%-40 \%$ or $0 \%-20 \%$, then the aspect was less and not good, so it must be revised

\section{RESULT AND DISCUSSION}

The development of e-learning with a constructive approach that can be usedby students ofFIP Unesa Education Technology Study Program in the course of photography was developed through five stages, starting from the stages of Analysis, Design, Development, Implementation, and Evaluation. All stages were carried out following the design of research that has been designed before, and product validation by validators and test subjects that students were conducted at the implementation stage using a measuring instrument in the form of a 
closed questionnaire. Questionnaires that have previously been validated by expert judgement to determine the feasibility of the questionnaire as a measuring instrument (Sugiyono, 2019). E-learning was conducted validity test by using questionnaire instrument to the learning design expert validator, material expert validator, and media expert validator. Here were the validity test results on each of the validators of this study:

Table 3. E-learning Feasibility Test Results with Constructivistic Approach

\begin{tabular}{lcc}
\hline \multicolumn{1}{c}{ Respondent } & Percentage & Criteria \\
\hline Learning Design Expert Validators & $96,66 \%$ & Very Decent \\
Validator Material Expert & $95 \%$ & Very Decent \\
Media Expert Validator & $95,58 \%$ & Very Decent \\
Education Technology Students & $88,37 \%$ & Very Decent \\
\hline
\end{tabular}

Based on Table 3 can be described that the validation applied to the validator of learning design experts using the Likert scale with the lowest score of 1 (one) and the highest 5 (five). The aspects assessed by learning design experts consist of three indicators; (1) format, which consists of tie sub-indicators: completeness of RPS and writing of RPS; (2) content, consisting of sub-indicators: completeness of identity of learning devices, accuracy of the description of basic competencies, conformity of learning indicators with essential competencies, suitability of time allocation with the achievement of indicators, conformity of learning objectives, conformity of materials to learning objectives, conformity of methods with learning objectives, use of relevant learning resources, conformity of learning activity measures to process standards, conformity of assessment techniques of learning outcomes; (3) language, which consists of sub-indicators: clarity of information, effective and efficient use of language, the message delivered following the rules of EYD (Ristekdikti, 2016). Based on the assessment of the learning design experts, the overall assessment is $96.66 \%$. The percentage is in the category of very good or very decent from the results of the calculation.

Validate application to material expert validators using the Likert scale with the lowest score of 1 (one) and the highest 5 (five). The aspects assessed by material experts consist of three indicators; (1) the content, which consists of sub indicators: conformity of the material presented in accordance with the development of students, the suitability of the material presented in accordance with the needs of the teaching material, the truth of the substance ofthe learning material, clarity of description, discussion, example, simulation, exercise, concept and definition of the material presented does not give rise to many interpretations, facts and data presented in accordance with reality and efficiently to improve the understanding of students; (2) language, which consists of sub indicators: readability of learning materials, clarity of learning materials, effective and efficient use of language, materials delivered in accordance with EYD rules; (3) the presentation, which consists of sub indicators: the material presented in order and easy to understand, the material presented reflects the distribution that supports the achievement of basic competencies, the material presented includes the material contained in the achievement indicators, the material presented includes the material contained in the learning objectives, the completeness of the material presented (Ristekdikti, 2016). Based on the assessment of the material design expert validator, the overall assessment is $95 \%$. From the results of the calculation, if faced with a criteria score, the percentage is in the category of very good or very decent.

Validate the application to the media expert validator using the Likert scale with the lowest score of 1 (one) and the highest 5 (five). The aspects assessed by media experts consist of four indicators; (1) content, which consists of sub-infdicators: learning media in accordance with SK and KD, learning media in accordance with the needs of learners, learning media in accordance with the needs of teaching materials, truth of material subtansi in learning media, learning media can add knowledge and insight for learners; (2) language, which consists of indicators: readability of words and sentences in the learning media, clarity of information conveyed in the learning media, effective and efficient use of language, messages delivered in the learning media in accordance with indonesian language rules; (3) the presentation, which consists of sub indicators: clarity of learning objectives delivered in the learning media, the order of presentation of materials in the learning media, the learning media can foster the motivation of learners in learning, the completeness of information in the learning media; (4) graphics, which consists of indicators: suitability of model and font size, suitability of layout and layout, appropriate use of illustrations, graphics, images and photos, attractiveness of learning media display design (Depdiknas, 2019). Based on the assessment of the media design expert validator, it was known that the overall rating was $95.58 \%$. From the results of the calculation, if faced with a criteria score then the percentage iss in the category of very good or very decent. Furthermore, based on the results of tests conducted on students, the overall assessment was $88.37 \%$. From the results of the calculation, if faced with a criteria score, the percentage was in the category of very good or very decent. This shows that students' response to constructive $e$ learning developed was good, and the application can be used as a learning medium. 


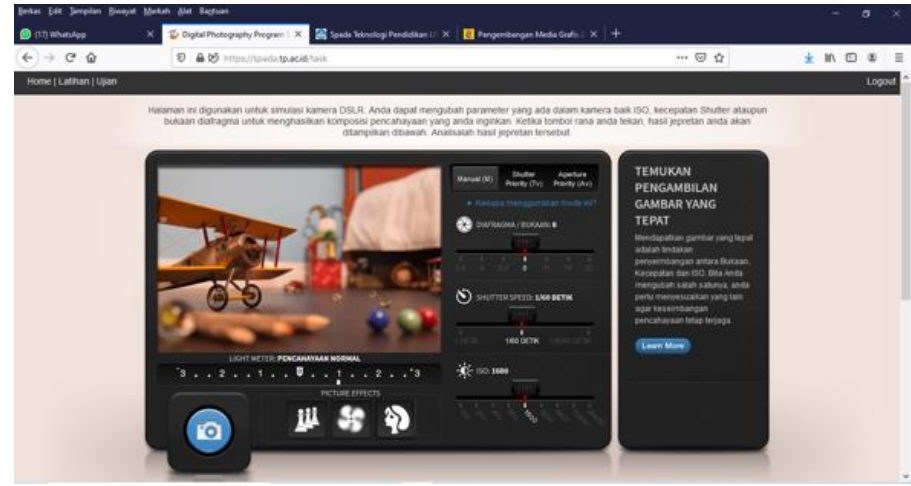

Figure 1. Display of E-Learning Material Triangle Exposure

Next, to see if product development was effective in learning, students were given a posttest after being given treatment. In determining the effectiveness of e-learning with a constructivist approach to the photography course, t-test analysis was used. T-test analysis calculation was done with the help of the SPSS program, with decision making based on the results of analysis if the value of asymp. Sig (2-tailed) $<0.05$ then constructivist $e$ learning is effectively used in learning. From the results of pretest and posttest given obtained the following results.

Table 4. Constructive E-learning Effectiveness Analysis

\begin{tabular}{|c|c|c|c|c|c|c|c|c|c|c|}
\hline \multicolumn{11}{|c|}{ Independent Samples Test } \\
\hline & & $\begin{array}{c}\text { Leve } \\
\text { Tes } \\
\text { Equa } \\
\text { Vari }\end{array}$ & $\begin{array}{l}\text { ne's } \\
\text { for } \\
\text { ity of } \\
\text { nces }\end{array}$ & \multicolumn{7}{|c|}{ t-test for Equality of Means } \\
\hline & & \multirow[b]{2}{*}{$\mathbf{F}$} & \multirow[b]{2}{*}{ Sig. } & \multirow[b]{2}{*}{$\mathbf{T}$} & \multirow[b]{2}{*}{ Df } & \multirow{2}{*}{$\begin{array}{c}\text { Sig. (2- } \\
\text { tailed) }\end{array}$} & \multirow{2}{*}{$\begin{array}{c}\text { Mean } \\
\text { Difference }\end{array}$} & \multirow{2}{*}{$\begin{array}{l}\text { Std. Error } \\
\text { Difference }\end{array}$} & $\begin{array}{r}95 \% \text { C } \\
\text { Interv } \\
\text { Diff } \\
\end{array}$ & $\begin{array}{l}\text { nfidence } \\
\text { al of the } \\
\text { rence }\end{array}$ \\
\hline & & & & & & & & & Lower & Upper \\
\hline \multirow[t]{2}{*}{$\begin{array}{l}\text { E- } \\
\text { Learning }\end{array}$} & $\begin{array}{l}\text { Equal } \\
\text { variances } \\
\text { assumed }\end{array}$ & 0.052 & 0.821 & 27.856 & 158 & 0.000 & 43.31250 & 1.55489 & 40.24146 & 46.38354 \\
\hline & $\begin{array}{l}\text { Equal } \\
\text { variances } \\
\text { not } \\
\text { assumed }\end{array}$ & & & 27.856 & 157.976 & 0.000 & 43.31250 & 1.55489 & 40.24145 & 46.38355 \\
\hline
\end{tabular}

\section{Discussions}

Table 4 showed that the results of calculations with t-test analysis obtained significance values based on asymp column. Sig (2-tailed) of 0.000 or significance $<0.05(0.000<0.05)$. Based on these calculations, the only differentiator in the learning process is the treatment of e-learning with a constructive approach, so what causes the difference in the value of posttest experimental classes is the treatment. Based on the description, it can be concluded that e-learning with an effective constructivist approach was used in the study photography courses. The results of the previous research stated that e-learning is better than conventional learning (Sudiarta \& Sadra, 2016). Learning using e-learning was very effective (Sulistiyoningsih et al., 2015). The previous results found that learning using e-learning was very effective (Putri \& Pujayanto, Yusliana, 2014). E-learning development was effective in improving learning outcomes (Kristanto et al., 2017). Based on the results of Sumarno research (2020), e-learning development was effectively used in learning. The results of media development in photography courses were feasible and effective in learning (Utrisa \& Mustaji, 2017). The difference between this research and the previous e-learning media in constructivist design means that students can construct their knowledge.

E-learning provides more guidance for online learning with distance learning while providing flexibility and accessibility for online learning. Furthermore, e-learning was suitable for students who live away from campus or have other commitments contrary to class time on campus. In addition, Learning through relevant and challenging online can increase learners' curiosity (Abramovitz et al., 2012). Online learning provides a safe, 
personalized and comfortable learning experience (Jogezai et al., 2021; Khan, 2013). E-learning contributes more to student learning achievement than traditional teaching methods (Yapici \& Akbayin, 2012). Meanwhile, E-learning contributed more to students' responses and critical levels when compared to traditional learning, and there was a positive correlation to learning outcomes (Korkmaz \& Karakus, 2019). E-learning contributes more to the outcomes of learning in subjects when compared to traditional learning. These findings are compatible with the literature in a study that examined changes in adult attitudes towards online courses. This was in line with the results of previous research (Kazua \& Demirkol, 2014). The average academic achievement of students who have studied with $e$-learning is higher than the average academic achievement of students who have studied in traditional learning environments. The fact that students can gain access to information in any place without being limited by boundaries or space with an e-learning environment The results of this study state that the $e$ learning environment improves average academic achievement while improving student learning outcomes in learning.

\section{CONCLUSION}

This development research facilitates products in the form of e-learning with a constructive approach. Based on the validation results of some experts and field trials, e-learning products with constructivist approaches that have been developed were feasible and effectively implied to be used in photography lectures. The advantage of this research is that e-learning was developed with a constructive approach to construct their knowledge.

\section{REFERENCES}

Abramovitz, B., Berezina, M., Berman, A., \& Shvartsman, L. (2012). A Blended Learning Approach in Mathematics. Teaching Mathematics Online: Emergent Technologies and Methodologies, 21. https://doi.org/10.4018/978-1-60960-875-0.ch002.

Amalia, F., \& Brata, A. H. (2018). Analisis Tingkat Penerimaan Sistem E-Learning menggunakan Blog Gratis sebagai Alternatif Media Pembelajaran pada Guru. Jurnal Teknologi Informasi Dan Ilmu Komputer, 5(3), 335. https://doi.org/10.25126/jtiik.201853640.

Arikunto, S., \& Cepi. (2010). Dasar-Dasar Evaluasi Pendidikan (Revision). Bumi Aksara.

Bahtiar, R. S. (2019). Efektivitas Penggunaan Media Papan Waktu Pada Pembelajaran Penghitungan Waktu Bagi Siswa Kelas Iii Sekolah Dasar. Jurnal Bidang Pendidikan Dasar, 3(1), 14-23. https://doi.org/10.21067/jbpd.v3i1.2857.

Baragash, R. S., \& Al-Samarraie, H. (2018). Blended learning: Investigating the influence of engagement in multiple learning delivery modes on students' performance. Telematics and Informatics, 35(7), 20822098. https://doi.org/10.1016/j.tele.2018.07.010.

Barry, M. (2012). What skills will you need to succeed in the future? Phoenix Forward (online). University of Phoenix.

Berga, K. A., Vadnais, E., Nelson, J., Johnston, S., Buro, K., Hu, R., \& Olaiya, B. (2021). Blended learning versus face-to-face learning in an undergraduate nursing health assessment course: A quasiexperimental study. Nurse Education Today, 96(October 2020), 104622. https://doi.org/10.1016/j.nedt.2020.104622.

Depdiknas. (2019). Panduan Pengembangan Bahan Ajar. Depdiknas.

Fitriyani, Y., Fauzi, I., \& Sari, M. Z. (2020). Motivasi Belajar Mahasiswa Pada Pembelajaran Daring Selama Pandemik Covid-19. Jurnal Kependidikan: Jurnal Hasil Penelitian Dan Kajian Kepustakaan Di Bidang Pendidikan, Pengajaran Dan Pembelajaran, 6(2), 165-175. https://doi.org/10.23917/ppd.v7i1.10973.

Hanum, N. S. (2013). Keefektifan E-learning Sebagai Media Pembelajaran (Studi Evaluasi Model Pembelajaran E-learning SMK Telkom Sandhy Putra Purwokerto. Jurnal Pendidikan Vokasi, 3, 90-102. https://doi.org/10.21831/jpv.v3i1.1584..

Hartanto, W. (2016). Penggunaan E-Learning Sebagai Media Pembelajaran. Jurnal Pendidikan Ekonomi: Jurnal Ilmiah Ilmu Pendidikan, Ilmu Ekonomi Dan Ilmu Sosial, 10(1). https://jurnal.unej.ac.id/index.php/JPE/article/view/3438.

Herliana, S., \& Anugraheni, I. (2020). Pengembangan Media Pembelajaran Kereta Membaca Berbasis Kontekstual Learning Siswa Sekolah Dasar. Jurnal Basicedu, 4(2), 314-326. https://doi.org/10.31004/basicedu.v4i2.346.

Hilliard, A. T. (2015). Global Blended Learning Practices for Teaching and Learning, Leadership and Professional Development. Journal of International Education Research, 11(3), 179-188. https://eric.ed.gov/?id=EJ1070786. 
Husaini, M. (2014). Pemanfaatan Teknologi Informasi dalam Bidang Pendidikan (E-Education). Jurnal Mikrotik, 2(1), 1-5. https://ojs.ummetro.ac.id/index.php/mikrotik/article/view/314 .

Jogezai, N. A., Baloch, F. A., Jaffar, M., Shah, T., Khilji, G. K., \& Bashir, S. (2021). Teachers' Attitudes Towards Social Media (SM) Use in Online Learning Amid The COVID-19 Pandemic: The Effects of SM Use by Teachers and Religious Scholars During Physical Distancing. Journal Heliyon, 7(4), 1-9. https://doi.org/10.1016/j.heliyon.2021.e06781.

Kazua, I. Y., \& Demirkol, M. (2014). Effect of Blended Learning Environment Model on High School Students' Academic Achievement. Turkish Online Journal of Educational Technology-TOJET, 13(1), 78-87. https://eric.ed.gov/?id=EJ1018177.

Khan, S. (2013). The One World Schoolhouse: Pendidikan Kelas Dunia untuk Siapapun di manapun (I). Penertbit Noura Books.

Korkmaz, O., \& Karakus, U. (2019). The Impact of Blended Learning Model on Student Attitudes Towards Geography Course and Their Critical Thinking Dispositions and Levels. The Turkish Online Journal of Educational Technology, 8(4). https://files.eric.ed.gov/fulltext/EJ859497.pdf .

Kristanto, A., Mustaji, \& Mariono, A. (2017). The development of instructional materials e-learning based on blended learning. Journal International Education Studies, 10(7), 10-17. https://doi.org/10.5539/ies.v10n7p10.

Maarop, A. H., \& Embi, M. A. (2016). Implementation of Blended Learning in Higher Learning Institutions: A Review of Literature. ResearchGate, 9(3), 41. https://doi.org/10.5539/ies.v9n3p4.

Mabruri, H., Ahmadi, F., \& Suminar, T. (2019). The Development of Science Mobile Learning Media to Improve Primary Students Learning Achievements Article Info. Journal of Primary Education, 8(1), 108-116. https://journal.unnes.ac.id/sju/index.php/jpe/article/view/25391.

Müller, A. M., Goh, C., Lim, L. Z., \& Gao, X. (2021). COVID-19 Emergency eLearning and Beyond: Experiences and Perspectives of University Educators. Education Sciences, 11(1), 19. https://doi.org/10.3390/educsci11010019.

Mustaji. (2017). Model dan desain pembelajaran: teori dan implementasi problem based learning dan collaborative learning. Unesa University Press.

Nichols, J. (2013). 4 Essential Rules of 21st Century Learning. http://www.teachthought.com/learning/4essential-rules-of-21stcentury-learning/

Nurhusain, M. (2017). Impact Analysis of Cooperative Learning Model Application Type Two Stay Two Stray (Tsts) Toward Learning Outcomes of Mathematics. JPMI (Jurnal Pendidikan Matematika Indonesia), 2(2), 46. https://doi.org/10.26737/jpmi.v2i2.220.

Nurrohmah, F., Putra, F. G., \& Farida, F. (2018). Development of Sparkol Video Scribe Assisted Learning Media. Formatif: Jurnal Ilmiah Pendidikan MIPA, 8(3), 233-250. https://doi.org/10.30998/formatif.v8i3.2613.

Pratama, L. D., Lestari, W., \& Astutik, I. (2020). Efektifitas Penggunaan Media Edutainment Di Tengah Pandemi Covid-19. AKSIOMA: Jurnal Program Studi Pendidikan Matematika, 9(2), 413-423. https://doi.org/10.24127/ajpm.v9i2.2783.

Putri, P. W., \& Pujayanto, Yusliana, E. (2014). Implementasi blended learning pada ipa tema pengelolaan sampah untuk meningkatkan kemampuan kognitif dan afektif (sikap) siswa kelas vii-d smpn 8 surakarta. Prosiding Seminar Nasional Fisika Dan Pendidikan Fisika, 48-54.

Ristekdikti. (2016). Puspawarna Pendidikan Tinggi Indonesia 2015. Pusat Data dan Informasi Ilmu Pengetahuan, Teknologi, dan Pendidikan Tinggi Kementerian Riset, Teknologi, dan Pendidikan Tinggi Republik Indonesia.

Rohmah. (2016). Konsep E-learning Dan Aplikasinya Pada Lembaga Pendidikan Islam. An-Nur.

Smaldino, S. E., Lowther, D. L., \& Russell, J. D. (2012). Instructional Technology \& Media For Learning Edisi Kesembilan diterjemahkan dari buku aslinya Instructional Technology and Media for Learning Pearson Education, Inc. Kencana Prenada Media Group.

Sudiarta, I. G. P., \& Suweken, G. (2014). Pengembangan Media Pembelajaran IKRAR Berbasis Video Untuk Meningkatkan Prestasi Belajar Siswa Kelas VII. Jurnal Pendidikan Matematika, 3(1). http://pasca.undiksha.ac.id/e-journal/index.php/JPM/article/view/1438.

Sudiarta, \& Sadra. (2016). Pengaruh model blended learning berbantuan video animasi terhadap kemampuan pemecahan masalah dan pemahaman konsep siswa. Jurnal Pendidikan Dan Pengajaran, 49(2), 48-58. https://doi.org/10.23887/jppundiksha.v49i2.9009.

Sugiyono. (2019). Metode Penelitian Kualitatif. Alfabeta.

Sulistiyoningsih, Kartono, \& Mulyono. (2015). PBL Bernuansa Adiwiyata dengan Blended Learning untuk Meningkatkan Kemampuan Pemecahan Masalah dan Karakter Peduli Lingkungan. Jurnal of $\begin{array}{llll}\text { Mathematics } & \text { Education } & \text { 84-92. }\end{array}$ https://journal.unnes.ac.id/sju/index.php/ujmer/article/view/9834/6286. 
Sundari, N. (2019). Penggunaan Media Gambar dalam Meningkatkan Keaktifan Siswa dalam Pembelajaran Pengetahuan Sosial di Sekolah Dasar. Journal of Chemical Information and Modeling, 53(9), 16891699.

Tantu, Y. R. P., \& Christi, L. Y. (2020). Analisis Pelaksanaan Microteaching Mahasiswa PGSD Pada Mata Kuliah PSAP Sains Dan Teknologi. Jurnal Basicedu, 3(2), 707-715. https://doi.org/10.31004/basicedu.v4i3.424.

Utrisa, \& Mustaji. (2017). Pengembangan media video mata pelajaran komposisi foto digital bagi siswa kelas XI multimedia di sekolah menengah kejuruan. Jurnal Kwangsan, 5(2), 91-100. https://doi.org/10.31800/jtp.kw.v5n2.p91--100.

Yapici, İ. Ü., \& Akbayin, H. (2012). The Effect of Blended Learning Model On High School Students Biology Achievement and On Their Attitudes Towards the Internet. The Turkish Online Journal Of Educational Technology, 11(2), 10. https://eric.ed.gov/?id=EJ989031. 